\title{
Polymyxin Acylase: Purification and Characterization, with Special Reference to Broad Substrate Specificity
}

\author{
Yukio KIMURA and Noriko Y ASUDA \\ Faculty of Pharmaceutical Sciences, Mukogawa Women's University, \\ 11-68, Koshienkyuban-cho, Nishimomiya 663, Japan \\ Received September 16, 1988
}

\begin{abstract}
Polymyxin acylase, which produces deacylated polymyxins by hydrolyzing only the fattyacyl groups of polymyxin antibiotics without affecting the peptide moiety, was purified from acetone-dried cell powder of Pseudomonas sp. M-6-3. The cell-free enzyme, solubilized by Triton X-100, was further purified on successive DEAE-cellulose, hydroxyapatite, and Sephacryl S-300 columns to a homogeneous state. This purified enzyme (Type I) had a single band with an MW of 62,000 in SDSpolyacrylamide gel electrophoresis. Gel filtration on a calibrated Sephacryl S-300 column also gave an estimated MW of 62,000. The isoelectric point of the enzyme was 5.7. Enzyme activity was optimal at pH 9.0 for colistin A (polymyxin $\mathrm{E}_{1}$ ) and was stable up to $50^{\circ} \mathrm{C}$ for $24 \mathrm{hr}$. The observed $V_{\max }$ and $\mathrm{Km}$ values were $1750 \mathrm{nmol} / \mathrm{min} / \mathrm{mg}$ and $3.85 \mathrm{~mm}$, respectively. This enzyme was almost not affected by metal chelators and various thiol-enzyme inhibitors (other than $p$-chloromercuribenzoate), and showed high tolerance for organic modifiers; for example, half of the activity remained in $\mathbf{5 0 \%}$ ethylene glycol buffer. This enzyme deacylated not only polymyxins but also various $N$-fattyacyl compounds (peptides and amino acids). Among several fattyacyl groups $\left(\mathrm{C}_{2}-\mathrm{C}_{16}\right)$ of $\mathrm{N}$-acyl DL-methionines, the caprinoyl $\left(C_{10}\right)$ group was most easily liberated, and the benzyloxycarbonyl $(Z)$ group was also slightly susceptible. When the enzyme was solubilized in $0.2 \mathrm{M} \mathrm{KCl}$-containing buffer by Triton X-100, the enzyme (Type II) showed a slightly different substrate specificity and an increased activity for some Zderivatives. With this enzyme, it is possible to remove the $Z$ group from several $Z$-peptides under mild conditions.
\end{abstract}

The acyl peptide antibiotics, polymyxin B and colistin (polymyxin E), have been used clinically against Gram-negative bacteria. However, little has been done to improve their therapeutic value by creating semisynthetic polymyxins via replacement of the acyl group. Previously, we found a strain, Pseudomonas sp. M-6-3, ${ }^{1+}$ which produces polymyxin acylase, a new enzyme for preparing the starting material for semisynthetic polymyxins. We showed that the cell-bound enzyme acts on polymyxin to produce deacylated polymyxin and fatty acid(s). Furthermore, the cell-bound enzyme can produce deacylated peptides from the acyl peptide antibiotics, cerexin (by Shoji \& Kato ${ }^{2)}$, brevistin (by Shoji \& Kato), ${ }^{3)}$ echinocandin B (by Pache et al.), ${ }^{4)}$ and neopeptin (by Ubukata et al.). ${ }^{51}$ This paper is concerned with the solubilization, purification, and characterization of polymyxin acylase from $P_{s e u}$ domanas sp. M-6-3. Since polymyxin acylase is unique in having a broader substrate specificity than several other known aminoacylases, it should be useful as a deacylating reagent for many $N$-acyl compounds.

\section{Materials and Methods}

Strain and growth conditions. Pseudomonas sp. M-6-3 strain was isolated in our laboratory from a soil sample from Nishinomiya, Japan. ${ }^{1)}$ The organisms were grown aerobically in medium containing $10 \mathrm{~g}$ of sodium citrate, $0.1 \mathrm{~g}$ of yeast extract, $2 \mathrm{~g}$ of $\left(\mathrm{NH}_{4}\right)_{2} \mathrm{SO}_{4}, 1 \mathrm{~g}$ of $\mathrm{K}_{2} \mathrm{HPO}_{4}$, $0.5 \mathrm{~g}$ of $\mathrm{MgSO}_{4} \cdot 7 \mathrm{H}_{2} \mathrm{O}, 0.01 \mathrm{~g}$ of $\mathrm{FeCl}_{3} \cdot 6 \mathrm{H}_{2} \mathrm{O}$, and $0.01 \mathrm{~g}$

Abbreviations: EDTA, ethylenediaminetetraacetic acid; EGTA, ethylene glycol bis( $\beta$-aminoethylether)- $N, N, N^{\prime}, N^{\prime}-$ tetraacetic acid; TPCK, $p$-toluenesulfonyl-L-phenylalanine chloromethyl ketone; TLCK, $p$-toluenesulfonyl-L-lysine chloromethyl ketone hydrochloride; DFP, disopropylphosphoro fluoridate; $\mathrm{Z}, \mathrm{N}$-benzyloxycarbonyl. 
of $\mathrm{CaCl}_{2} \cdot 2 \mathrm{H}_{2} \mathrm{O}$ per liter of water at pH 7.5 which was shaken at $28^{\circ} \mathrm{C}$ for $72 \mathrm{hr}$. The bacterial mass was harvested, and the acetone-dried cell powder was prepared by the usual method, giving a yield of $0.9 \mathrm{~g} / 1$.

Chemicals. Colistin sulfate was kindly supplied by the Banyu Pharmaceutical Co. (Tokyo, Japan). Colistin A was prepared from a colistin complex by HPLC and $N$ fattyacyl methionines were prepared by the water-soluble active ester method ${ }^{6)}$ from the appropriate fattyacyl ester of $p$-dimethylsulfoniophenol methylsulfate and methionine in our laboratory. $N$-Benzyloxycarbonyl peptides were the generous gifts of Dr. M. Fujino, Takeda Chemical Industries, Ltd. (Osaka, Japan). All other chemicals were purchased from Nakarai Chemicals Ltd. (Kyoto, Japan).

Enzyme assay. Polymyxin acylase was assayed from the UV-absorption peak of deacylated peptide on HPLC (method 1). Acylase activity for acyl amino acids was assayed by the ninhydrin color of the liberated amino acid (method 2). Urethane hydrolase activity for $N$-benzyloxycarbonyl derivatives was assayed from the UVabsorption of the liberated benzyl alcohol on HPLC (method 3).

Assay method 1 . The reaction mixture, $200 \mu \mathrm{l}$, containing $2 \mu \mathrm{mol}$ of colistin sulfate and the enzyme solution $(100 \mu)$ in $50 \mathrm{~mm}$ Tris buffer (pH 9.0), was incubated at $37^{\circ} \mathrm{C}$ for several hours. After each hour, $100 \mu 1$ of $1 \mathrm{~N}$ $\mathrm{H}_{2} \mathrm{SO}_{4}$ was added and the mixture was filtered using a $0.45-\mu \mathrm{m}$ filter (TOSOH, Tokyo, Japan). A $10-\mu \mathrm{l}$ portion of the filtrate was injected into the HPLC [column, Ultrasphere ODS $5 \mu \mathrm{m}(4.6 \times 250 \mathrm{~mm})$ (Beckman, U.S.A.); mobile phase, $\mathrm{MeOH}: 0.01 \mathrm{~N}_{2} \mathrm{SO}_{4}=1: 1$; detector, $\mathrm{UV}$ $(210 \mathrm{~nm})]$. The amount of deacyl colistin was calculated from the height of the peak on the chromatogram. One unit of enzyme activity was defined as the amount of enzyme that produced $1 \mathrm{nmol}$ of deacyl colistin per min.

Assay method 2. The reaction mixture, $200 \mu \mathrm{l}$, containing $10 \mu \mathrm{mol}$ of acyl amino acid (usually $N$-capryloyl-DLmethionine) sodium salt, and the enzyme solution $(100 \mu \mathrm{l})$ in $50 \mathrm{~mm}$ Tris buffer $(\mathrm{pH} 8.0)$, was incubated at $37^{\circ} \mathrm{C}$ for several hours. The reaction mixture was treated as in method 1 and the amount of liberated amino acid in $100 \mu \mathrm{l}$ of the filtrate was measured colorimetrically by the ninhydrin method.

Assay method 3. The reaction mixture, $200 \mu$ l, containing $1 \mu \mathrm{mol} N$-benzyloxycarbonyl peptide and the enzyme solution $(100 \mu \mathrm{l})$ in $50 \mathrm{~mm}$ Tris buffer $(\mathrm{pH} 8.0)$ was treated as in method 1. Next, $10 \mu \mathrm{l}$ of the enzyme reaction solution was injected into the HPLC [column, Shodex OHpak B$804(8.0 \times 500 \mathrm{~mm})$ (Showa Denko Co., Ltd., Tokyo, Japan); mobile phase, water; detector, UV (210 nm)]. The amount of the liberated benzyl alcohol was calculated from the height of the peak on the chromatogram.

Solubilization of the enzyme from acetone-dried cell powder. The powder prepared above $(100 \mathrm{mg})$ was used throughout the following treatments.

a) Sonication: The powder was suspended in $10 \mathrm{ml}$ of $100 \mathrm{~mm}$ phosphate buffer ( $\mathrm{pH} 7.2$ ), and disrupted in the presence of a few drops of toluene with a $10 \mathrm{kHz}$ ultrasonic oscillator for $30 \mathrm{~min}$. The cellular debris was removed by centrifugation at $10,000 \times g$ for $30 \mathrm{~min}$.

b) EDTA-Lysozyme: The powder was suspended in $10 \mathrm{ml}$ of $5 \mathrm{~mm}$ phosphate buffer ( $\mathrm{pH} \mathrm{6.8)}$ ), containing $50 \mu \mathrm{mol} \mathrm{EDTA}$ and $50 \mu \mathrm{mol} 2$-mercaptoethanol, and then digested by the addition of egg white lysozyme $(100 \mu \mathrm{g} / \mathrm{ml})$ at $30^{\circ} \mathrm{C}$ for $4 \mathrm{hr}$. The broth was centrifuged to remove cellular debris.

c) Colistin: The powder was suspended in $10 \mathrm{ml}$ of $10 \mathrm{~mm}$ phosphate buffer ( $\mathrm{pH} 7.2$ ), containing $1 \mathrm{mg}$ of colistin sulfate and $1 \mu \mathrm{mol} 2$-mercaptoethanol. The mixture was stirred at $28^{\circ} \mathrm{C}$ for $15 \mathrm{hr}$, and centrifuged.

d) Triton X-100: The powder was suspended in $10 \mathrm{ml}$

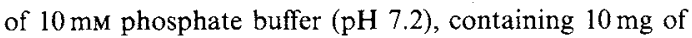
Triton X-100 and $1 \mu \mathrm{mol} 2$-mercaptoethanol. The mixture was stirred at $28^{\circ} \mathrm{C}$ for $15 \mathrm{hr}$ and then centrifuged.

Protein measurement. Protein was measured by the method of Lowry et al., ${ }^{7}$ with bovine serum albumin (Sigma Chemical Co., U.S.A.) as the standard. In all chromatographic procedures the protein concentration was measured by the absorbance at $280 \mathrm{~nm}$.

Purification of enzyme. One gram of acetone-dried cell powder of Pseudomonas sp. M-6-3 was suspended in $30 \mathrm{ml}$ of $10 \mathrm{~mm}$ phosphate buffer ( $\mathrm{pH} 8.0$ ) containing $100 \mathrm{mg}$ of Triton X-100. The suspension was stirred at $20^{\circ} \mathrm{C}$ for $15 \mathrm{hr}$ and then centrifuged at $10,000 \times g$ for $30 \mathrm{~min}$. The supernatant was put on a DEAE-cellulose (DE53; Whatman, U.K.) column $(1.5 \times 21 \mathrm{~cm}$; equilibrated with $10 \mathrm{~mm}$ phosphate buffer at pH 8.0), eluted first with the same buffer, and then with a linear gradient from 0 to $500 \mathrm{mM} \mathrm{KCl}$ in the equilibration buffer. The active fractions were effectively eluted in the first step. Because the capacity of the column was small, this procedure was repeated several times and the active fractions were pooled. The enzyme from the above step was put on a hydroxyapatite (Nippon Chemical Co., Japan) column $(1.5 \times 14 \mathrm{~cm}$; equilibrated with $10 \mathrm{~mm}$ phosphate buffer at $\mathrm{pH} 8.0$ ), eluted first with the same buffer, and then with a linear gradient from 10 to $500 \mathrm{~mm}$ of phosphate $(\mathrm{pH} 8.0)$. The active fractions emerged at two peaks: Fr. I, which showed the most enzyme activity, was re-chromatographed on a hydroxyapatite column as above. The resulting active fractions were combined and then concentrated with a Millipore Immersible-CX Ultrafilter. This concentrated enzyme was put on a Sephacryl S-300 (Pharmacia Fine Chemicals Co., Sweden) column $(1.5 \times 82 \mathrm{~cm}$; equilibrated with $10 \mathrm{~mm}$ phosphate buffer at pH 8.0). The lower molecular weight fraction was re-chromatographed on a Sephacryl S-300 column. The enzyme, which showed a single peak, was eluted and all samples were pooled. 
Enzyme homogeneity. The purified enzyme was dialyzed against distilled water, and the Triton X-100 in the enzyme solution was removed with chloroform. ${ }^{8}$ SDS-polyacrylamide gel electrophoresis was done by the method of Weber and Osborn, ${ }^{9}$, with a $7.5 \%$ polyacrylamide gel and phosphate buffer $(\mathrm{pH} 7.0)$. Electrophoresis was done at $8 \mathrm{~mA}$ per column and gels were stained with Coomassie brilliant blue R-250.

Isoelectric point. Isoelectric-focusing electrophoresis was done by the method of Vesterberg and Svensson ${ }^{10)}$ using an isoelectrofocusing column $(2.5 \times 30 \mathrm{~cm})$ (LKBProdukter. AB, Sweden) and $1 \%$ carrier Ampholine ( $\mathrm{pH}$ $3 \sim 10$ ); electrophoresis was done at $4^{\circ} \mathrm{C}$ and $700 \mathrm{~V}$ for $45 \mathrm{hr}$.

Measurement of molecular weight. The MW of the purified enzyme was measured by gel filtration on a Sephacryl S-300 column $(1.5 \times 80 \mathrm{~cm})$ by the method of Andrews, ${ }^{11)}$ using a standard protein kit (Pharmacia Fine Chemicals Co., Sweden). SDS-polyacrylamide gel (7.5\%) electrophoresis as described above was also used to measure the MW of the enzyme.

\section{Results}

Purification of polymyxin acylase from Pseudomonas sp. M-6-3

Because polymyxin acylase is bound to the cell envelope, one of the critical steps in purifying it is solubilizing the enzyme from the cell. As shown in Table I, Triton X-100 treatment gave the best yield of the soluble enzyme, although colistin, a substrate of polymyxin acylase, solubilized the enzyme to a lesser extent. The cell free extract solubilized by Triton X-100 was purified by three-stage chromatography; the results are summarized in Table II. Figure IA shows the chromatographic profile of the enzyme on a DEAEcellulose column with a linear gradient of $\mathrm{KCl}$. Using colistin as substrate, $90 \%$ of the deacylase activity was detected in the passed solution and $10 \%$ in the $500 \mathrm{~mm}-\mathrm{KCl}$ eluate. The enzyme was further purified twice by hydroxyapatite column chromatography (Fig. 1B) and then twice by Sephacryl S-300 column chromatography. When enzyme homogeneity was assessed by SDS-polyacrylamide gel electrophoresis, a single band of protein was observed (Fig. 2). The properties of the purified
Table I. The Enzyme ACtivity Solubilized from ACETONE-DRIED Cell Powder BY VARIOUS TREATMENTS

\begin{tabular}{lcc} 
Methods & $\begin{array}{c}\text { Treatment } \\
\text { time } \\
\text { (hr) }\end{array}$ & $\begin{array}{c}\text { Solubilized } \\
\text { enzyme activity } \\
\text { (units/100 mg powder) }\end{array}$ \\
\hline Sonic & 0.5 & 4,000 \\
EDTA-Lyzozyme & 4 & 900 \\
Colistin & 15 & 3,600 \\
Triton X-100 & 15 & 7,800 \\
\hline
\end{tabular}

Table II. Purification of PolymyXin ACylase FROM Pseudomonas SP. M-6-3

\begin{tabular}{lrrrr}
\hline Purification step & $\begin{array}{c}\text { Total } \\
\text { protein } \\
\text { (mg) }\end{array}$ & $\begin{array}{c}\text { Total } \\
\text { activity } \\
\text { (units) }\end{array}$ & $\begin{array}{c}\text { Specific } \\
\text { activity } \\
\text { (units/mg) }\end{array}$ & $\begin{array}{c}\text { Yield } \\
(\%)\end{array}$ \\
\cline { 3 - 5 } Cell-free extract & 137.0 & 47,300 & 340 & 100 \\
DEAE-cellulose & 64.4 & 41,900 & 650 & 89 \\
1st Hydroxyapatite & 23.1 & 31,200 & 1,350 & 66 \\
2nd Hydroxyapatite & 19.9 & 31,000 & 1,560 & 66 \\
1st Sephacryl S-300 & 9.5 & 16,400 & 1,720 & 35 \\
2nd Sephacryl S-300 & 6.4 & 11,200 & 1,750 & 24 \\
\hline
\end{tabular}

enzyme were as follows:

\section{Stability}

The enzyme was stable for only 5 weeks at $4^{\circ} \mathrm{C}$, but the presence of $0.1 \mathrm{M}$ ammonium sulfate or $1 \%$ bovine serum albumin increase the period of stability to 4 months. Although the enzyme was stable up to $50^{\circ} \mathrm{C}$ for $24 \mathrm{hr}$, there was a marked loss of activity after storing at $-40^{\circ} \mathrm{C}$, and also after incubating at over $60^{\circ} \mathrm{C}$ for $1 \mathrm{hr}$.

\section{Optimal $\mathrm{pH}$ and temperature}

The optimal $\mathrm{pH}$ was 9.0 for colistin $\mathrm{A}$ and the optimal temperatures of the enzyme was about $45 \sim 50^{\circ} \mathrm{C}$ (although Pseudomonas sp. M-6-3 itself cannot tolerate temperatures over $35^{\circ} \mathrm{C}$ ). The observed $V_{\max }$ and $K m$ values were $1750 \mathrm{nmol} / \mathrm{min} / \mathrm{mg}$ and $3.85 \mathrm{~mm}$, respectively. For $N$-capryloyl-DL-methionine, these values were $2470 \mathrm{nmol} / \mathrm{min} / \mathrm{mg}$ and $3.0 \mathrm{~mm}$.

\section{Measurement of $M W$ and isoelectric point}

The MW of the purified enzyme was esti- 

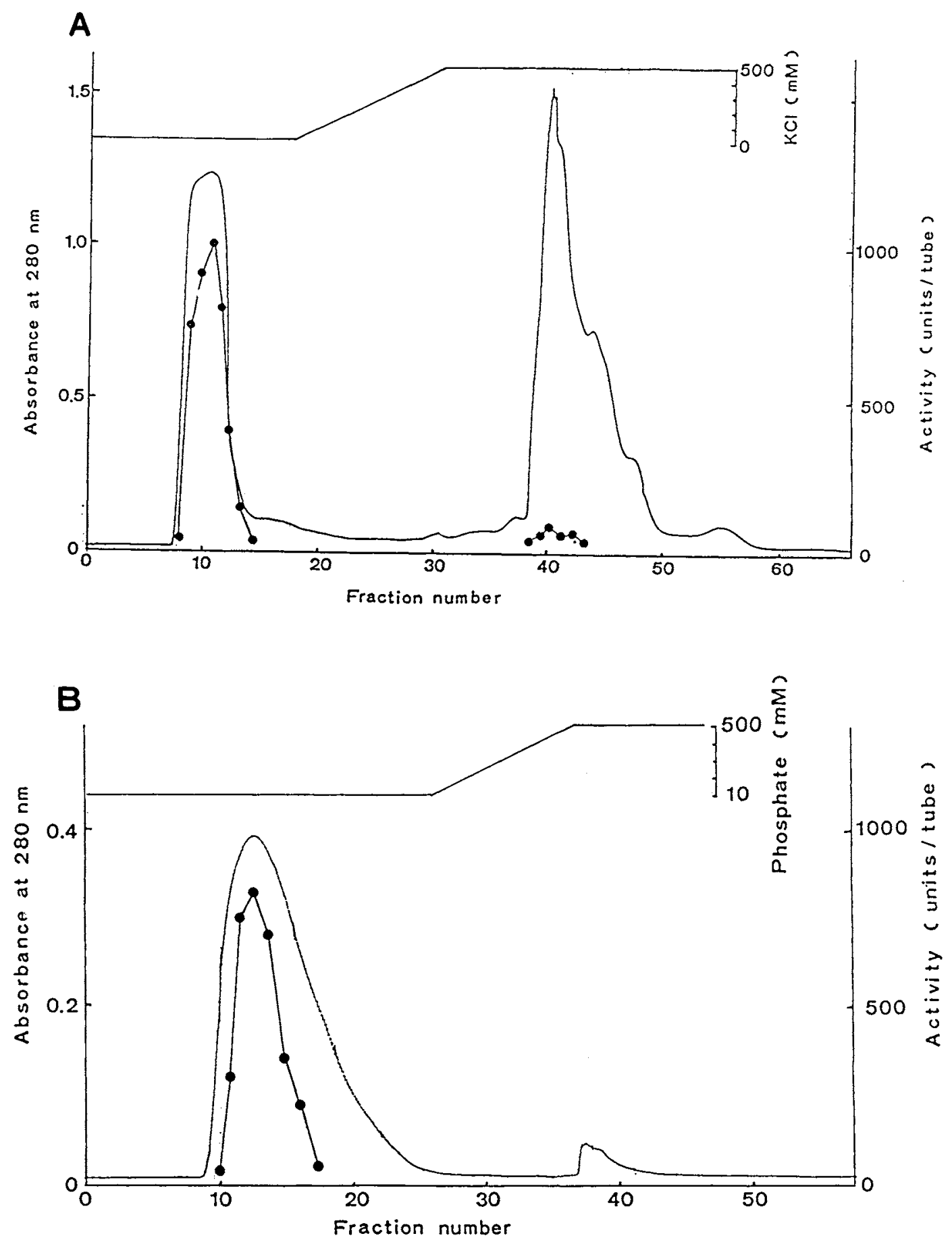

Fig. 1. Column Chromatography of the Polymyxin Acylase on DEAE-Cellulose (A) and Hydroxyapatite (B).

Eluent: (A) $10 \mathrm{~mm}$ phosphate buffer ( $\mathrm{pH} 8.0$ ) and then with a linear gradient from 0 to $500 \mathrm{mM} \mathrm{KCl}$ in the buffer; (B) $10 \mathrm{~mm}$ phosphate buffer $(\mathrm{pH} 8.0)$ and then with a linear gradient from 10 to $500 \mathrm{~mm}$ of phosphate buffer; flow rate, $48 \mathrm{ml} / \mathrm{hr}$; fraction, $3 \mathrm{ml} / \mathrm{tube}$; _ , absorbance at $280 \mathrm{~nm}$; - , enzyme activity. 


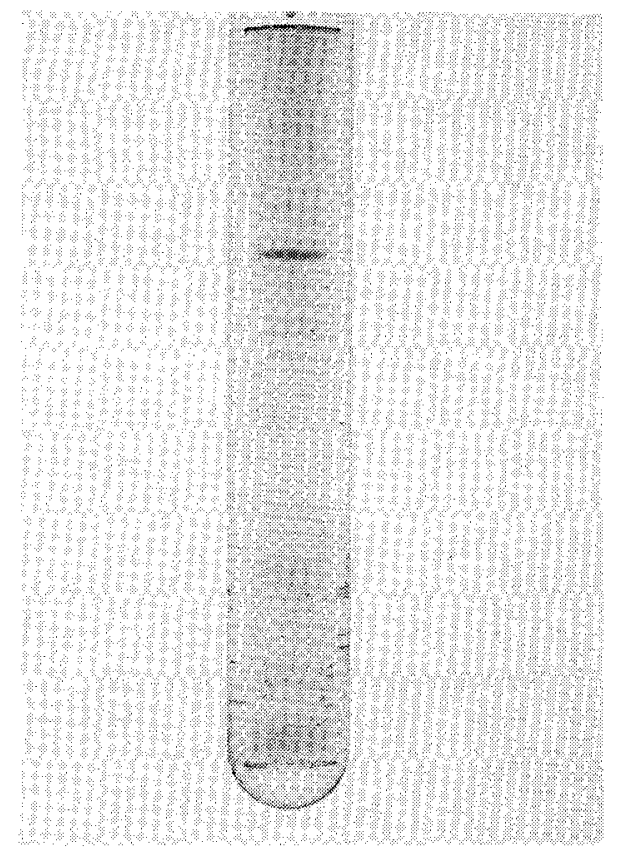

Fig. 2. SDS-Polyacrylamide Gel Electrophoresis of the Purified Polymyxin Acylase (Type I).

mated to be 62,000 by gel filtration chromatography on Sephacryl S-300, but occasionally a high molecular weight peak that had the same enzyme activity emerged. The MW calculated by SDS-polyacrylamide gel electrophoresis was 62,000 , which agrees well with gel filtration method. The isoelectric point was 5.7 , as measured by isoelectricfocusing electrophoresis.

Effects of metal ions, chemical reagents, and inhibitors

The enzyme activity was markedly inhibited by $\mathrm{Hg}^{2+}$ and $\mathrm{Ag}^{+}$, although the other cations $\left(\mathrm{Mg}^{2+}, \mathrm{Ca}^{2+}, \mathrm{Mn}^{2+}, \mathrm{Fe}^{2+}, \mathrm{Fe}^{3+}, \mathrm{Co}^{2+}, \mathrm{Ni}^{2+}\right.$, $\mathrm{Cu}^{2+}, \mathrm{Zn}^{2+}, \mathrm{Cd}^{2+}, \mathrm{Ba}^{2+}$, and $\mathrm{Pb}^{2+} ; 1 \mathrm{mM}$ ) had little effect. Metal-ion chelating agents (EDTA, EGTA, o-phenanthroline, 8-hydroxyquinoline) did not inhibit the enzyme over the concentration range $0.1 \sim 1.0 \mathrm{~mm}$, but $20 \mathrm{~mm}$ EGTA inhibited about $50 \%$ of the activity. Neither thiol-protease inhibitors (other than $p$ chloromercuribenzoate) nor serine protease inhibitor (DFP) affected the enzyme activity. TPCK and TLCK did not inhibit. The enzyme

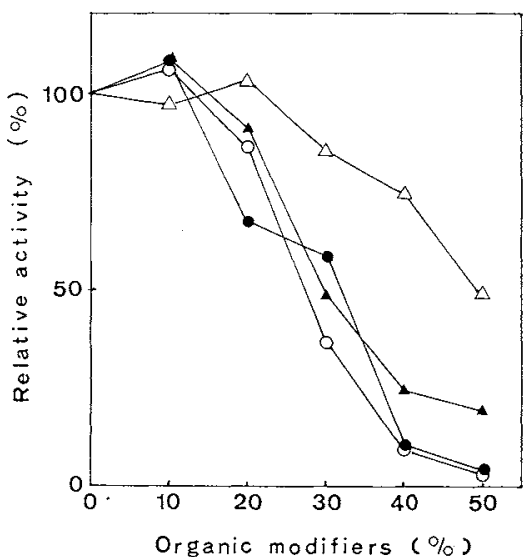

Fig. 3. Effects of Organic Modifiers on the Activity of Polymyxin Acylase (Type I).

The enzyme activity was measured in the presence of various concentrations of organic modifiers by assay method 2. $\bigcirc-O$, methanol; - - ethanol; $\triangle-\triangle$, ethylene glycol; $\boldsymbol{\Lambda}-\mathbf{A}, N, N^{\prime}$-dimethylformamide.

Table III. Substrate SPECIFICITy OF POLYMyXIN ACYLASE (TYPE I)

\begin{tabular}{|c|c|}
\hline Substrate & $\begin{array}{c}\text { Relative } \\
\text { activity } \\
(\%)\end{array}$ \\
\hline Acetyl- $\left(\mathrm{C}_{2}\right)$-DL-methionine & 3.0 \\
\hline Butyroyl-( $\left.\mathrm{C}_{4}\right)$-DL-methionine & 2.3 \\
\hline Caproyl- $\left(\mathrm{C}_{6}\right)$-DL-methionine & 64 \\
\hline Capryloyl- $\left(\mathrm{C}_{8}\right)$-DL-methionine & 100 \\
\hline Capryloyl- $\left(\mathrm{C}_{8}\right)$-DL-aspartic acid & 122 \\
\hline Capryloyl- $\left(\mathrm{C}_{8}\right)$-DL-glutamic acid & 131 \\
\hline Capryloyl-( $\left.\mathrm{C}_{8}\right)$-DL-glycine & 116 \\
\hline Capryloyl-( $\left.\mathrm{C}_{8}\right)$-DL-alanine & 111 \\
\hline Capryloyl- $\left(\mathrm{C}_{8}\right)$-DL-valine & 105 \\
\hline Capryloyl- $\left(\mathrm{C}_{8}\right)$-DL-leucine & 83 \\
\hline Capryloyl- $\left(\mathrm{C}_{8}\right)$-DL-serine & 98 \\
\hline Capryloyl- $\left(\mathrm{C}_{8}\right)$-DL-threonine. & 95 \\
\hline Capryloyl-( $\left(\mathrm{C}_{8}\right)$-DL-phenylalanine & 83 \\
\hline Caprinoyl- $\left(\mathrm{C}_{10}\right)$-DL-methionine & 107 \\
\hline Lauroyl- $\left(C_{12}\right)$-DL-methionine & 100 \\
\hline Myristoyl- $\left(\mathrm{C}_{14}\right)$-DL-methionine & 85 \\
\hline Palmitoyl-( $\left.\mathrm{C}_{16}\right)$-DL-methionine & 56 \\
\hline Benzoyl-DL-methionine & 0.36 \\
\hline Benzyloxycarbonyl-DL-methionine & 0.25 \\
\hline
\end{tabular}

was inhibited by two oxidizing agents, $\mathrm{N}$ bromosuccinimide and potassium ferricyanate.

\section{Tolerance for organic modifiers}

The enzyme showed tolerance for several 
Tabłe IV. Difference of Substrate Specificity of PolymyXin Acylases (Types I AND II) ON SEveral N-BENZyLOXYCARBONYL AMINO ACIDS

\begin{tabular}{lcc}
\hline \multirow{2}{*}{ Substrate } & \multicolumn{2}{c}{ Relative activity $(\%)$} \\
\cline { 2 - 3 } & Type I & Type II \\
\hline Capryloyl-DL-methionine & 100 & 62 \\
Z-DL-Glutamic acid & 5.7 & 18 \\
Z-DL-Aspartic acid & 2.9 & 8 \\
Z-DL-Methionine & 0.25 & 0.3 \\
Z-DL-Glycine & 0.2 & 0.6 \\
Z-DL-Alanine & 0.2 & 0.6 \\
Z-DL-Tyrosine & 0.1 & 0.2 \\
\hline
\end{tabular}

Table V. Removal of $N$-BenzyloxyCARBONYL Group Using Polymyxin ACylase (Type II)

The reaction mixture (containing 170 units of enzyme) was incubated at $37^{\circ} \mathrm{C}$ for $48 \mathrm{hr}$ and the removal of the $\mathrm{Z}$ group was confirmed by assay method 3 .

Substrate

\section{Z-Glu(OBu')-Ser-Thr-Leu}

Z-Ser-Glu(OBu ${ }^{\mathrm{t}}$-Lys(Boc)-Ser-Glu-Thr-Pro

Z-Gly-Gly

Z-Gly-Gly-NH

Z-Gly-Phe

Z-Ala-Thr- $\mathrm{NH}_{2}$

Z-Pro-Ser-Asp $\left(\mathrm{OBu}{ }^{t}\right)$-Thr-Pro-Ile-Leu-Pro-

$\mathrm{Gln}-\mathrm{OBu}{ }^{\mathrm{t}}$

Z-Pro-Glu(OBu $)$-Ile

+ , completely removed; - , not removed.

organic modifiers shch as methanol, ethanol, ethylene glycol, and dimethyl formamide (Fig. 3 ). Even in $50 \%$ ethylene glycol buffer, half of the activity remained.

\section{Substrate specificity}

Interestingly, this enzyme had a broader substrate specificity than was expected; for example, it hydrolyzed all of the $N$-acyl D- and L-amino acids that were studied. In the case of $\mathrm{N}$-acyl methionines, the enzyme was particularly active for long chain fattyacyl groups, especially capryloyl $\left(\mathrm{C}_{8}\right)$, caprinoyl $\left(\mathrm{C}_{10}\right)$, and lauroyl $\left(\mathrm{C}_{12}\right)$ groups, but also hydrolyzed $\mathrm{N}$ acetyl and $N$-benzoyl DL-methionine slightly (Table III). The activity of the enzyme was equivalent for all $N$-capryloyl amino acids, regardless of the amino acid residues (Table III).

On the other hand, when the enzyme was solubilized by the Triton X-100 method in $0.2 \mathrm{M} \mathrm{KCl}$-containing buffer and was purified in the same way, a single homogeneous protein could not be obtained, and this only partially purified preparation showed a slightly different specificity pattern. The relative activity increased for Z-amino acids (Table IV). We called this enzyme preparation Type II to distinguish it from the enzyme solubilized without $\mathrm{KCl}$ (Type I). Despite its rather weak activity, a large amount of the Type II enzyme was able to split the $Z$ group of several $Z$ peptides much more readily than the Type I could. The results are summarized in Table V.

\section{Discussion}

Since Schmiedberg ${ }^{12)}$ observed enzymatic hydrolysis of $\mathrm{N}$-benzoyl-glycine in the late 19 th century, many kinds of enzymes which are able to hydrolyze $N$-acyl amino acids have been reported. In the early stages, interest centered around the optical resolution of racemic amino acids, as exemplified by the work of Greenstein et al. with hog kidney acylases, ${ }^{13)}$ Kameda et al. with bacterial acylases, ${ }^{14)}$ and Chibata et al. with fungus acylases. ${ }^{15)}$ In the late fifties, interest shifted to penicillin-deacylating enzyme(s) and their use in preparing semisynthetic penicillin. Rolinson et $a .^{16)}$ and Kameda et al. ${ }^{17)}$ published some of the earliest reports; this was followed by a spate of related reports. An earlier paper of ours ${ }^{1)}$ reported the isolation of a polymyxindeacylating enzyme (polymyxin acylase) in the cell-bound form and its use in preparing deacyl colistin. The cell-bound enzyme deacylated not only polymyxins but also various $N$-fatty acyl peptides and $N$-acyl amino acids. The substrate specificity of the cell-bound enzyme distinguishes it from other aminoacylase, which usually can hydrolyze $N$-acyl amino acids but not $N$-acyl peptides. In these experiments, we solubilized and purified this new enzyme. We found that the substrate, colistin, is able 
to solubilize the cell-bound enzyme; this is consistent with Teuber's observation that polymyxin-lysozyme caused spheroplast formation in Salmonella. ${ }^{18)}$ A suspension of the acetone-dried cell powder of Pseudomonas sp. M-6-3 was effective as the enzyme source because of the detergent-activity of colistin on the cell-bound enzyme. The solubilization ability of Triton X-100 was even higher than that of colistin. The solubilizing data in Table I suggest that this enzyme is periplasmic.

After purifying the solubilized enzyme by three-stage column chromatography, we identified it as a single protein by SDS-polyacrylamide gel electrophoresis. The enzyme had a molecular weight of approximately 62,000 and in the presence of Triton X-100, it was liable to polymerize. The properties (substrate specificity, $\mathrm{pH}$-stability, heat tolerance, etc.) were very similar to those of the cellbound enzyme, although the optimum $\mathrm{pH}$ of the purified enzyme was slightly higher. Like $N$-long chain acyl aminoacylase from $P$ seudomonas diminuta, ${ }^{19)}$ chelators such as EDTA and 8-hydroxyquinoline showed no effects on enzyme activity. This is consistent with the inertness of metal ions toward enzyme activity. Also serine protease inhibitors were not active. The activity of polymyxin acylase was not affected by various sulfhydryl agents other than $p$-chloromercuribenzoate.

The most interesting property of this enzyme(s) was its broad substrate specificity. Especially, the specificity for the amino moiety is not exact; for example the activities for $N$ capryloyl amino acids were indistinguishable, regardless of the amino acid residues; it acted not only on the L-form but also on the D-form, and L-form was more easily hydrolyzed. Furthermore, even $N$-capryloyl derivatives having an amino moiety, such as glucosamine, were hydrolyzed by this enzyme. ${ }^{20)}$ This polymyxin acylase is particularly active on long chain fattyacyl groups, like that of amino acylase from Mycobacterium phlei ${ }^{21)}$ or Pseudomonas dismuta. ${ }^{17)}$ Interestingly, different conditions in enzyme solubilization gave different specificity patterns for the solubilized enzyme. "Type I enzyme," solubilized without $\mathrm{KCl}$, was more active towards $N$-fattyacyl amino acids; while "Type II enzyme," solubilized with $\mathrm{KCl}$, was more active for Z-amino acids. The mechanism of the formation of Type II is not clear. At present, there are two possible explanations of these results. The first would postulate the existence of both types of enzymes in the cell-bound form. The second possibility is that Type I and Type II enzymes originate from the same protein in the cell. The solution of this problem requires the purification of both types and the determination of their amino acid sequences.

Recently, Soda et al. $^{22)}$ purified, chrystallized, and characterized a kind of amino acylase from Bacillus stearothermophilus. Their enzyme contains $2 \mathrm{~g}$ atoms of zinc per mole of protein, however polymyxin acylase (Types I and II) contains calcium, and its substrate specificity is far from that of their enzyme. Murao et al. ${ }^{23)}$ reported some papers concerning urethane-hydrolyzing enzymes from Lactobacillus fermenti, but their enzymes did not act on Z-peptides. Polymyxin acylase (Type II) removed the $Z$ group of some $Z$-peptides. We believe that both types of polymyxin acylase will have many practical applications in peptide chemistry; two obvious examples are in applying the Edman degradation to naturally occurring $N$-acyl peptides, and in preparing analogs of $N$-acyl peptides.

\section{References}

1) Y. Kimura, H. Matsunaga, N. Yasuda, T. Tatsuki and T. Suzuki, Agric. Biol. Chem., 51, 1617 (1987).

2) J. Shoji and T. Kato, J. Antibiot., 28, 764 (1975).

3) J. Shoji and T. Kato, J. Antibiot., 29, 380 (1976).

4) W. Pache, C. Keller and M. Kuhn, Experimentia, 34/12, 1671 (1978).

5) M. Ubukata, M. Uramoto and K. Isono, Tetrahedron Lett., 25, 423 (1984).

6) K. Kouge, T. Koizumi and H. Okai, "Peptide Chemistry 1986," Protein Research Foundation, Osaka, 1987, p. 237.

7) O. H. Lowry, N. J. Rosebrough, A. L. Farr and R. J. Randall, J. Biol. Chem., 193, 265 (1951).

8) S. Horikawa and H. Ogawara, Anal. Biochem., 97, $116(1979)$ 
9) K. Weber and M. Osborn, J. Biol. Chem., 244, 4406 (1969).

10) O. Vesterberg and H. Svensson, Acta Chem. Scand., 20, 820 (1966).

11) P. Andrews, Biochem. J., 96, 595 (1965).

12) O. Schmiedberg, Arch. Exptl. Pathol. Pharmakol., 14, 379 (1881).

13) J. P. Greenstein, "Methods in Enzymology," Vol. 3, ed. by S. P. Colowick and N. O. Kaplan, Academic Press Inc., New York, 1957, pp. 554 570.

14) Y. Kameda, K. Matsui, Y. Kimura, E. Toyoura and M. Kimura, Chem. Pharm. Bull., 10, 1146 (1962).

15) I. Chibata, T. Tosa, T. Sato and T. Mori, "Methods in Enzymology," Vol. 44, ed. by K. Mosbach, Academic Press Inc., New York, 1976, pp. 746 759.

16) G. N. Rolinson, F. R. Batchelor, D. Butterworth, J. Cameron-Wood, M. Cole, G. C. Eustace, Marian V.
Hart, M. Richards and E. B. Chain, Nature, 187, 236 (1960).

17) Y. Kameda, Y. Kimura, E. Toyoura and T. Omori, Nature, 191, 1122 (1961).

18) M. Teuber, Arch. Mikrobiol, 70, 139 (1970).

19) Y. Shintani, H. Fukuda, N. Okamoto, K. Murata and A. Kimura, J. Biochem., 96, 637 (1984).

20) Y. Kimura, H. Matsunaga and N. Yasuda, "Peptide Chemistry 1987," Protein Research Foundation, Osaka, 1988, p. 435.

21) Y. Kameda, E. Toyoura and Y. Kimura, The Annual Report of the Faculty of Pharmacy, Kanazawa University, 9, 23 (1957).

22) H. Y. Cho, K. Tanizawa, H. Tanaka and K. Soda, J. Biochem., 103, 622 (1988).

23) E. Matsumura, E. Yamamoto, T. Kawano, T. Shin and S. Murao, Agric. Biol. Chem., 50, 1563 (1986). 